\title{
PENGEMBANGAN MEDIA PEMBELAJARAN PADA KOMPETENSI DASAR MEMBACA GAMBAR MENERAPKAN SISTEM KOORDINAT BERBASIS ADOBE FLASH
}

\author{
Rika Dewi Indriyani ${ }^{1}$, Tiwan ${ }^{2}$, Dwi Rahdiyanta ${ }^{3}$ \\ 1,2,3 Program Studi Pendidikan Teknik Mesin, Fakultas Teknik, Universitas Negeri Yogyakarta \\ Email: rikadewi054@gmail.com
}

\begin{abstract}
This research aimed to design and assess the feasibility of Adobe Flash aided learning media for CNC Turning subject, specifically for the coordinate system topic. The research was a research and development study using the Four-D models of development. Four-D model consists of 4 steps, namely define, design, develop, and disseminate. The instrument being used on this research was closed questionnaires with 4 choices Likert scale. The questionnaires were validated by expert evaluation. Data were collected from the 32 respondents. Data, which were quantitative and qualitative, were analyzed using descriptive-analysys technique. Result shows that the learning media meets the teachers' and students' needs and expectation. For the feasibility level, the contents expert gave an average score of 3.37 which can be categorized as "very good". The expert in media gave an average score of 3.45 which is in the "very good" category. The Teacher of the respective subject gave an average score of 3.38 and is categorized as "very good". Students respond well with a score of 3.47 were given, which can be categorized as "very good".
\end{abstract}

Keywords: research and development, learning media, flash, cnc turning coordinate

\begin{abstract}
ABSTRAK
Tujuan penelitian ini adalah merancang media pembelajaran berbantuan adobe flash untuk mata pelajaran CNC Turning dengan sistem koordinat. Penelitian ini merupakan penelitian pengembangan dengan model pengembangan Four-D Models yang terdiri dari 4 tahap yaitu define, design, develop, dan disseminate. Instrumen yang digunakan berupa angket dengan skala Likert 4 pilihan jawaban. Angket divalidasi oleh ahli evaluasi. Pengambilan data dilakukan kepada 32 responden. Data kualitatif dan kuantitatif yang diperoleh dianalisis menggunakan teknik analisis deskriptif. Hasil penelitian menunjukkan bahwa media pembelajaran yang dikembangkan telah disesuaikan dengan kebutuhan dan tuntutan dari guru dan siswa. Tingkat kelayakan media pembelajaran menurut ahli materi mendapatkan rerata nilai sebesar 3,37 dengan kategori "sangat baik". Hasil validasi ahli media memperoleh rerata nilai sebesar 3,45 dengan kategori "sangat baik". Hasil validasi guru pengampu memperoleh rerata nilai sebesar 3,38 dengan kategori "sangat baik". Berdasarkan penilaian respon siswa diperoleh rerata sebesar 3,47 dengan kategori "sangat baik".
\end{abstract}

Kata kunci: penelitian pengembangan, media pembelajaran flash, cnc turning

\section{PENDAHULUAN}

Pendidikan sangat penting untuk menghadapi persaingan saat ini, terutama dengan negara-negara maju di seluruh dunia yang menuntut generasi anak bangsa agar pintar dan cerdas. Dalam Undang-undang No. 20 Tahun 2003 pasal 1 ayat (1) tentang Sistem Pendidikan Nasional menyatakan bahwa pendidikan adalah usaha sadar dan terencana untuk mewujudkan suasana belajar dan proses pembelajaran agar peserta didik secara aktif mengembangkan potensi dirinya untuk memiliki kekuatan spiritual keagamaan, pengendalian diri, kepribadian, kecerdasan, akhlak mulia serta keterampilan yang diperlukan dirinya, masyarakat, bangsa dan negara. Berbagai mata pelajaran telah dikembangkan yang tujuan akhirnya adalah lahirnya para intelektual yang nantinya dapat diandalkan sebagai agen perubahan yang dapat membawa suatu negara mampu bersaing dengan negara lain. Upaya peningkatan kualitas 
pendidikan terus-menerus dilakukan, baik secara konvensional maupun inovatif. Peningkatan yang dilakukan berupa perubahanperubahan dalam berbagai komponen sistem pendidikan seperti kurikulum, strategi pembelajaran, alat bantu belajar, sumbersumber belajar dan sebagainya.

Sesuai standar proses yang ditetapkan dalam Standar Nasional Pendidikan, proses pembelajaran pada satuan pendidikan diselenggarakan secara interaktif, inspiratif, menyenangkan, memotivasi peserta didik, untuk berpartisipasi aktif, serta memberikan ruang cukup bagi kemadirian dan perkebangan fisik maupun psikologis peserta didik. Guru diharapkan dapat mengelola kelas secara efektif dan efisien (Dimyati dan Mudjiono, 2013: 239).

Berdasarkan wawancara yang diperoleh dari guru mata pelajaran serta pengalaman penulis di SMK N 2 Klaten siswa sulit memahami dan membayangkan pembuatan pemograman, sehingga banyak siswa mengalami kesulitan dalam memahami materi pelajaran dan akhirnya beranggapan bahwa mata pelajaran CNC Turning merupakan mata pelajaran yang sulit karena siswa hanya mengandalkan catatannya sendiri dari hasil penjelasan dengan model demonstrasi yang diberikan oleh gurunya.

Cara penyampaian dengan model demonstrasi ini kurang interaktif dan terkadang membuat siswa kurang memahami pembacaan gambar secara menyeluruh. Ole karena itu, perlu dikembangkan media pembelajaran yang membuat siswa sebagai pengguna lebih tertarik dan memahami materi dan fungsi serta prinsip kerja pengguna yaitu dengan memanfaatkan multimedia. Pembelajaran memanfaatkan multimedia dipilih karena dapat menjelaskan lebih detail dan lebih fokus melalui tampilan yang ditayangkan melalui proyektor. Gambar yang disampaikan lebih besar dan lebih jelas (Muhammad Munir, 2014: 184-190). Selain itu, materi CNC turning bersifat pemahaman bukan hafalan sehingga perlu adanya referensi tambahan berupa media pembelajaran untuk membantu siswa memahami sistem koordinat yang sifatnya interaktif. Adanya media pembelajaran sistem koordinat diharapkan dapat meningkatkan prestasi belajar siswa .

Berdasarkan ulasan yang diuraikan diatas, Maka didapatkan tujuan penelitian yang akan merancang media pembelajaran sistem koordinat berbantuan adobe flash dan mengetahui kelayakan media pembelajaran dalam mata pelajaran CNC Turning dengan sistem koordinat diharapkan dapat membantu siswa dan guru dalam melaksanakan proses belajar mengajar. Media pembelajaran ini berupa materi dalam bentuk media pembelajaran menggunakan Adobe Flash Prefesional 6 di dalamnya akan disajikan materi, animasi, evaluasi, dan video.

\section{METODE}

Penelitian ini merupakan penelitian pengembangan atau Research and Development (R\&D) yaitu pengembangan media pembelajaran pada mata pelajaran $\mathrm{CNC}$ turning menggunakan Adobe Flash. Prosedur pengembangan mengacu pada Four-D models, sebagaimana disampaikan oleh Thiagarajan dan Semmel (Trianto, 2009: 189). Four-D models menerapkan 4 tahap pengembangan yang harus diikuti yaitu tahap define, design, develop, dan disseminate. Model tersebut diadaptasi menjadi model 4-P yaitu pendefinisian (define), perancangan (design), pengembangan (develop), penyebaran (disseminate).

Keempat tahap tersebut dapat dijelaskan sebagai berikut. (1) Pendefinisian (define) yang meliputi tahap analisis ujung depan, analisis siswa, analisis tugas, analisis konsep, dan perumusan tujuan pembelajaran. Perancangan (design) yang meliputi tahap penyusunan tes acuan patokan, tahap pemilihan media, pemilihan format. (3) Pengembangan (develop) meliputi validasi perangkat oleh para pakar diikuti dengan revisi, simulasi, uji coba terbatas dengan siswa sesungguhnya. (4) Penyebaran (disseminate) merupakan tahap penggunaan perangkat yang telah 
dikembangkan pada skala yang lebih luas, misalnya sekolah lain, kelas lain. Tahap penyebaran ini dilakukan terbatas dengan memberikan hasil produk pengembangan ke sekolah (Trianto, 2009: 189).

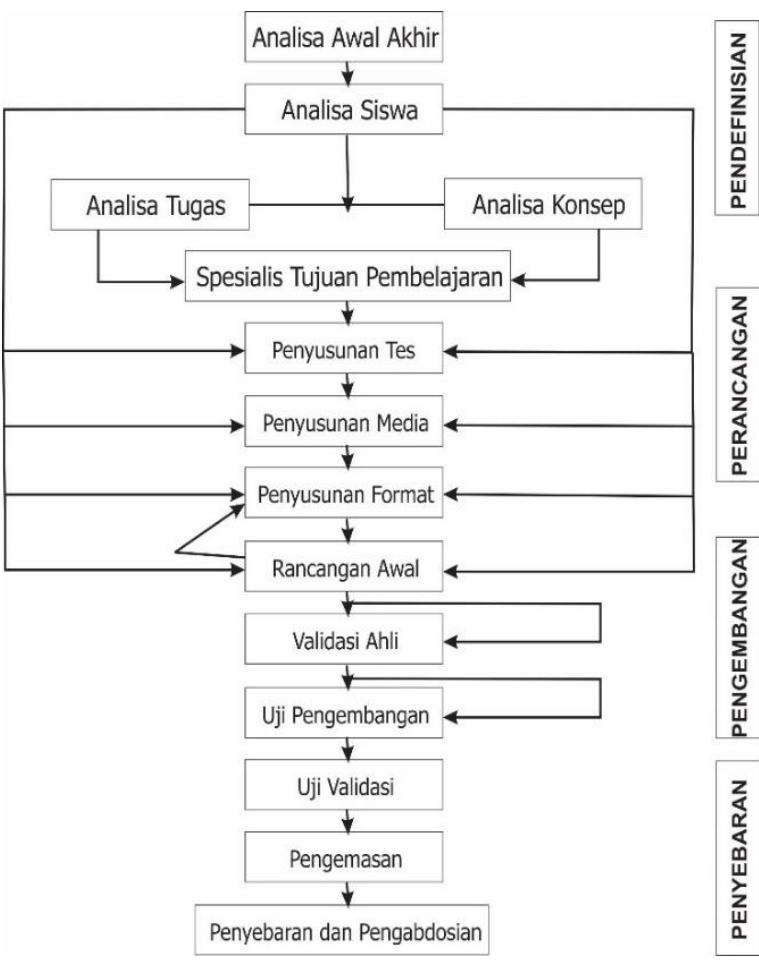

Gambar 1. Langkah Pengembangan Media Pembelajaran (Trianto, 2009: 189)

Tahap define bertujuan untuk menetapkan dan mendefinisikan berbagai sumber informasi berkaitan dengan produk yang akan dikembangkan. Tahap define meliputi 3 langkah yaitu analisis awal, analisis siswa dan kurikulum, juga merumuskan tujuan. Tahap design bertujuan untuk merancang produk yang akan dikembangkan. Produk awal atau prototype harus sesuai standar kelayakan agar dapat diterapkan di lapangan. Tahap perancangan ini terdiri dari empat langkah yaitu penyusunan garis besaar isi media pembelajaran mendesain isi pembelajaran pada media pembelajaran, pemilihan format, pembuatan desain awal media pembelajaran. Tahap develop merupakan suatu tahap untuk menghasilkan produk pengembangan. Tujuan dari tahap ini yaitu untuk menghasilkan bentuk akhir perangkat pembelajaran setelah melalui revisi berdasar-kan masukan dari validator dan data hasil uji coba pengembangan. Pada tahap pengembangan melalui 2 langkah yaitu: (1) penilaian ahli (expert appraisal) yang diikuti dengan revisi dan (2) uji coba pengembangan (development testing). Berikut penjelasan dari masing-masing langkah. Tahap akhir penelitian pengembangan $4 D$ models adalah tahap penggunaan perangkat yang telah dikembangkan pada skala yang lebih luas, misalnya sekolah lain, di kelas yang lain dan guru lain. Tahap disseminate dalam penelitian ini tidak dapat dilakukan karena lingkup penelitian yang sempit yakni terbatas dalam satu sekolah.

Penelitian dilakukan di SMK Negeri 2 Klaten kelas XI Teknik Permesinan A yang beralamat di Senden, Senden, Ngawen, Klaten. Penelitian dilaksanankan pada bulan Desember 2016 - Januari 2017. Subjek dalam penelitian ini adalah 1 dosen ahli materi, 1 dosen ahli media, 1 guru pengampu mata pelajaran, dan siswa kelas XI TPM A sejumlah 32 siswa. Objek penelitian adalah media pembelajaran yang dikembangkan.

Data yang diambil merupakan data hasil validasi ahli media, ahli materi, guru pengampu dan siswa. Instrumen yang digunakan berupa lembar validasi ahli dan kuisoner siswa. Teknik pengumpulan data dilakukan dengan teknik observasi, dokumentasi dan kuisioner.

Teknik analisis data yang digunakan adalah teknik analisis deskriptif. Analisis deskriptif digunakan untuk mengetahui kelayakan media pembelajaran CNC turning. Skala pengukuran menggunakan skala Likert dengan empat pilihan jawaban: Sangat Baik (skor 4), Baik (skor 3), Kurang Baik (skor 2), dan Tidak Baik(skor 1). Analisis data yang menggunakan Persamaan 1 (S. Eko Putro Widoyoko, 2014: 110)

Jarak Interval $=\frac{\text { Skor Tertinggi }- \text { Skor Terendah }}{\text { Jumlah Kelas Interval } \quad \ldots . .(1)}$

Jarak interval tersebut kemudian dibuatkan tabel klasifikasi produk untuk 
menilai produk yang dihasilkan seperti pada Tabel 1.

Tabel 1. Tabel Klasifikasi Produk

\begin{tabular}{|c|c|c|}
\hline No. & Rerata Skor & Klasifikasi Produk \\
\hline 1. & $1,00 \quad$ s/d 1,75 & Tidak Baik \\
\hline 2. & $>1,75 \mathrm{~s} / \mathrm{d} 2,50$ & Kurang Baik \\
\hline 3. & $>2,50 \mathrm{~s} / \mathrm{d} 3,25$ & Baik \\
\hline 4. & $>3,25 \mathrm{~s} / \mathrm{d} 4,00$ & Sangat Baik \\
\hline
\end{tabular}

Nilai rerata skor dari setiap aspek yang telah ditentukan dihitung dengan Persamaan 2.

$$
\begin{aligned}
& \text { Rerata Skor Aspek }=\frac{\text { Jumlah Total Skor Setiap Aspek }}{\text { Jumlah Responden X Jumlah }} \\
& \text { Butir Instrumen }
\end{aligned}
$$

Untuk mendapatkan katagori layak pada sebuah produk minimal berada pada skor 2,50 atau dalam klasifikasi "Baik".

\section{HASIL DAN PEMBAHASAN}

$\begin{array}{rlr}\text { Pada } & \text { tahap pendefinisian } & \text { (define) } \\ \text { dilakukan } & \text { analisis } & \text { kebutuhan }\end{array}$ pembelajaran, analisis siswa dan kurikulum, serta perumusan tujuan. Hasil dari analisis tahap pendefinisian ini, diperlukan media pembelajaran yang mampu menunjang kegiatan pembelajaran yang menarik sehingga menunjang kegiatan pembelajaran. Media yang dipilih berupa media pembelajaran berbantuan adobe flash yang berisi materi dan instruksi yang dapat mengasah kemampuan siswa dalam pelajaran $\mathrm{CNC}$ turning dengan sistem koordinat. Hal tersebut didasari dari hasil analisis siswa yang memiliki karakter yang cenderung pasif dan tidak memperhatikan guru yang menyampaikan materi.

Pada analisis kurikulum, diketahui kurikulum yang digunakan adalah kurikulum 2013. Hasil diskusi dengan guru pengampu didapatkan solusi untuk mengembangkan media pembelajaran berupa media pembelajaran flash pada mata pelajaran CNC turning yang akan difokuskan pada kompetensi dasar menerapkan pekerjaan pada CNC turning, khususnya mengenai teknik pemrograman dasar.
Pada tahap perancangan (design), materi pembelajaran dibagi menjadi beberapa bagian, yaitu 3 bagian materi pokok, 1 video tutorial, dan 2 bagian soal evaluasi yaitu soal pilihan ganda dan soal pemograman. Selain kegiatankegiatan tersebut, pada tahap perancangan ini juga mempertimbangkan kebutuhan dan tuntutan dari guru dan siswa untuk menghasilkan media pembelajaran yang terdiri dari materi belajar, gambar, animasi, simulasi, dan evaluasi yang dikemas secara menarik dalam satu kesatuan dengan menggunakan software Adobe Flash Professional CS6.

Tahap berikutnya yaitu pengembangan (development). Pada tahap ini, produk awal divalidasi oleh ahli materi dan ahli media untuk dinilai kelayakannya. Hasil revisi dari ahli ditindaklanjuti sebagai perbaikan dalam pengembangan media pembelajaran. Kemudian media pembelajaran yang sudah direvisi dan mendapatkan validasi dari para ahli diujicobakan pada siswa kelas XI TPM A di SMKN 2 Klaten yang berjumlah total 32 siswa menggunakan instrumen angket respon siswa yang sudah valid. Hasil dari penilaian angket respon siswa dijadikan acuan untuk memperbaiki isi media pembelajaran sehingga produk akhir media pembelajaran telah selesai dibuat.

Pada tahap penyebaran dilakukan penyebaran penggunaan media pembelajaran CNC turning dengan skala yang lebih luas yaitu pada sekolah lain atau kelas lain. Tahap ini tidak diadopsi serta tidak dilaksanakan terkait dengan penelitian yang sebatas pada pengembangan serta uji kelayakan. Tahap penyebaran dilakukan terbatas pada lingkup sekolah yang diteliti khususnya kelas Teknik Permesinan kelas A di SMK N 2 Klaten. Kendala lain dikarenakan keterbatasan waktu, biaya dan tenaga untuk menyebarkan media pembelajaran CNC turning dengan sistem koordinat yang sudah dikembangkan pada instansi lain.

Penilaian isi materi media pembelajaran flash dilakukan oleh 1 ahli materi. Penilaian media pembelajaran dari ahli materi pada aspek 
kualitas materi dengan skor 3,33 masuk dalam klasifikasi "sangat baik"; aspek isi/materi dengan skor 3,45 masuk dalam klasifikasi "sangat baik"; dan aspek strategi pembelajaran dengan skor 3,33 masuk dalam klasifikasi "sangat baik".. Ahli materi menilai kelayakan media pembelajaran flash dengan rata-rata skor 3,37 masuk dalam klasifikasi "sangat baik". Lembar validasi dapat dilihat pada Tabel 2.

Tabel 2. Hasil Analisis Data Ahli Materi

\begin{tabular}{llcc}
\hline No. & Aspek Penilaian & Rerata & Klasifikasi \\
\hline 1 & Aspek Kualitas & 3,33 & Sangat baik \\
& Materi & & \\
2 & Aspek isi materi & 3,45 & Sangat baik \\
3 & $\begin{array}{l}\text { Aspek strategi } \\
\text { pembelajaran }\end{array}$ & 3,33 & Sangat baik \\
\hline & Rata-rata & 3,37 & Sangat baik \\
\hline
\end{tabular}

Selain data di atas, terdapat juga masukan dari ahli materi yaitu: perlunya penambahan materi dalam memperjelas kode bubut tirus dan bubut radius, memperjelas kesinambungan dengan sistem koordinat yang ada dalam pembelajaran, dan membuat evaluasi tambahan untuk mempermudahkan penyampaian materi.

Penilaian lain mengenai media pembelajaran flash dilakukan oleh 1 ahli media. Penilaian media pembelajaran dari ahli media pada aspek konsep media dengan skor 3,5 masuk dalam klasifikasi "sangat baik"; dan aspek tampilan media dengan skor 3,41 masuk dalam klasifikasi "sangat baik". Ahli media menilai kelayakan media dengan skor rata-rata keseluruhan 3,45 masuk dalam klasifikasi "sangat baik". Lembar validasi dapat dilihat pada Tabel 3.

Tabel 3. Hasil Analisis Data Ahli Media

\begin{tabular}{llrr}
\hline No. & Aspek Penilaian & Rerata & Klasifikasi \\
\hline 1 & $\begin{array}{l}\text { Aspek Konsep } \\
\text { Media }\end{array}$ & 3,50 & Sangat Baik \\
2 & $\begin{array}{l}\text { Aspek Tampilan } \\
\text { Media }\end{array}$ & 3,41 & Sangat Baik \\
\hline & Rata-rata & 3,45 & Sangat baik \\
\hline
\end{tabular}

Selain data di atas, terdapat juga masukan dari ahli media yaitu perlunya perbaikan definisi sistem koordinat, perbaikan huruf, perbaikan latar belakang, perbaikan warna, perbaikan keterbacaan gambar, perbaikan materi sistem koordinat, dan sinkronisasi materi dengan tujuan.

Penilaian media pembelajaran flash juga dilakukan oleh 1 guru pengampu mata pelajaran CNC. Penilaian media pembelajaran dari materi pada aspek kualitas materi dengan skor 3,17 masuk dalam klasifikasi "sangat baik"; aspek isi/ materi dengan skor 3,67 masuk dalam klasifikasi "sangat baik"; dan aspek strategi pembelajaran dengan skor 3,38 masuk dalam klasifikasi "sangat baik"; juga penilaian dari media pada aspek konsep media dengan skor 3,37 masuk dalam klasifikasi "sangat baik", dan aspek tampilan media dengan skor 3,33 masuk dalam klasifikasi "sangat baik". Guru pengampu menilai kelayakan media pembelajaran flash dengan rata-rata skor 3,38 masuk dalam klasifikasi "sangat baik". Lembar validasi dapat dilihat pada Tabel 4.

Tabel 4. Hasil Analisis Data Guru Pengampu

\begin{tabular}{|c|c|c|c|c|}
\hline No. & Aspek & aian & Rerata & Klasifikasi \\
\hline \multirow[t]{2}{*}{1} & \multicolumn{2}{|c|}{ Aspek Konsep Media } & 3,37 & Sangat Baik \\
\hline & Aspek & Tampilan & & \\
\hline \multirow[t]{2}{*}{2} & Media & & 3,33 & Sangat Baik \\
\hline & Aspek & Kualitas & & \\
\hline \multirow[t]{2}{*}{3} & Materi & & 3,17 & Baik \\
\hline & \multicolumn{2}{|c|}{ Aspek Isi/Materi } & & \\
\hline 4 & Aspek & Strategi & 3,67 & Sangat Baik \\
\hline \multirow[t]{2}{*}{5} & Pembe & & 3,38 & Sangat Baik \\
\hline & Rat & & 3,38 & Sangat baik \\
\hline
\end{tabular}

Uji coba produk media pembelajaran flash ini melibatkan 32 siswa kelas XI Teknik Permesinan di SMKN 2 Klaten. Hasil penilaian angket respon 32 siswa dari aspek pembelajaran dengan skor 3,53 masuk dalam klasifikasi "sangat baik"; materi dengan skor 3,35 masuk dalam klasifikasi "sangat baik"; konsep media dengan skor 3,56 masuk dalam klasifikasi "sangat baik"; tampilan media pembelajaran dengan skor 3,56 masuk dalam klasifikasi "sangat baik"; dan tampilan media dengan skor 3,50 masuk dalam klasifikasi "sangat baik". Pada empat aspek tersebut didapatkan rata-rata skor kelayakan total sebesar 3,48 masuk dalam 
klasifikasi "sangat baik". Lembar validasi dapat dilihat pada Tabel 5.

Selain data di atas, terdapat juga masukan-dari siswa yaitu: kedepannya lebih baik materi pada software ditingkatkan lagi dan diupload ke playstore, kedepannya lebih baik materi pada software ditingkatkan dan dikembangkan lagi agar mudah dimengerti.

Tabel 5. Hasil Analisis Data Siswa

\begin{tabular}{|c|c|c|c|}
\hline No. & Aspek Penilaian & Rerata & Klasifikasi \\
\hline 1 & $\begin{array}{l}\text { Aspek Pembelajaran } \\
\text { Aspek Materi }\end{array}$ & 3.53 & Sangat Baik \\
\hline 2 & Aspek Konsep Media & 3.35 & Sangat Baik \\
\hline 3 & $\begin{array}{l}\text { Aspek } \\
\text { Media }\end{array}$ & 3.56 & Sangat Baik \\
\hline 4 & & 3.50 & Sangat Baik \\
\hline & Rata-rata & 3,48 & Sangat baik \\
\hline
\end{tabular}

Kelayakan pengembangan media pembelajaran ini dapat diketahui dari hasil penilaian ahli materi dengan skor 3,37 masuk dalam klasifikasi "sangat baik"; ahli media dengan skor 3,45 masuk dalam klasifikasi "sangat baik"; guru pengampu dengan skor 3,38 masuk dalam klasifikasi "sangat baik", dan respon siswa dengan skor 3,48 masuk dalam klasifikasi "sangat baik" (Tabel 6). Penilaian ke ahli materi dan ahli media dilakukan sebelum dilakukan sebelum produk digunakan uji coba, Penilaian kepada Guru Pengampu dilakukan settelah di nilaikan dengan Ahli Media,dan Ahli Materi kemudian ke siswa atau uji coba lapangan. Produk yang dinyatakan layak oleh ahli, kemudian dilakukan uji coba penggunaan produk ke siswa. Berikut hasil analisis penilaian kelayakan media pembelajaran flash oleh ahli materi, ahli media, dan respon siswa.

Selain data di atas, guru pengampu tidak memberikan masukan dan kritik yang dianggap oleh guru pengampu sudah layak digunakan tanpa perbaikan dan dapat digunakan dalam metode pembelajaran di kelas XI Teknik Permesinan.
Tabel 6. Hasil Validasi Keseluruhan

\begin{tabular}{|c|c|c|c|c|}
\hline No. & Pihak Penil & & Rerata & Klasifikasi \\
\hline 1. & $\begin{array}{l}\text { Validasi } \\
\text { Materi }\end{array}$ & Ahli & 3,37 & Sangat Baik \\
\hline 2. & $\begin{array}{l}\text { Validasi } \\
\text { Media }\end{array}$ & Ahli & 3,45 & Sangat Baik \\
\hline 3. & $\begin{array}{l}\text { Validasi } \\
\text { Pengampu }\end{array}$ & Guru & 3,38 & Sangat Baik \\
\hline 4. & Siswa & & 3,48 & Sangat Baik \\
\hline & Rata-rata & & 3,42 & Sangat Baik \\
\hline
\end{tabular}

\section{SIMPULAN}

Hasil uji kelayakan media pembelajaran dari ahli materi yang mencakup aspek konsep materi, isi/ materi, dan strategi pembelajaran memperoleh rerata keseluruhan sebesar 3,37 dan termasuk dalam klasifikasi "sangat baik". Hasil validasi ahli media mencakup aspek konsep media, aspek tampilan media didapatkan rerata keseluruhan sebesar 3,45 masuk dalam klasifikasi "sangat baik". Hasil validasi guru pengampu mencakup aspek konsep media, aspek tampilan media, konsep materi,isi/materi dan strategi pembelajaran didapatkan rerata keseluruhan sebesar 3,38 masuk dalam klasifikasi "sangat baik". Hasil uji coba terhadap siswa kelas XI Teknik Permesinan A yang berjumlah 32 didapatkan skor rata-rata keseluruhan 3,48 masuk dalam klasifikasi "sangat baik". Berdasarkan hasil tersebut, dapat disimpulkan bahwa media pembelajaran flash layak digunakan dalam kegiatan belajar mengajar (KBM) karena skor minimal untuk mencapai skor layak adalah sebesar 2,50 pada klasifikasi "baik".

Berdasarkan hasil penelitian dari pengembangan media pembelajara flash, berikut beberapa saran yang dapat peneliti sampaikan: (1) Bagi guru dan siswa diharapkan dapat memanfaatkan media pembelajaran yang sudah berhasil dikembangkan tersebut untuk digunakan dalam kegiatan pembelajaran pada mata pelajaran CNC Turning menerapkan sistem koordinat. (2) Bagi peneliti selanjutnya disarankan untuk menguji efektivitas dari media pembelajaran berbantuan adobe flash pada mata pelajaran CNC Turning menerapkan sistem 
koordinat ini, karena penelitian yang sudah dilakukan masih sebatas menguji kelayakan dari media pembelajaran tersebut. (3) Media pembelajaran yang dikembangkan dapat dijadikan referensi pada penelitian serupa. Harapannya jika media yang dikembangkan ini masih terdapat beberapa kelemahan pada penelitian selanjutnya hal tersebut dapat diatasi, sehingga diperoleh media yang lebih baik untuk dijadikan sumber belajar.

\section{DAFTAR RUJUKAN}

Dimyati dan Mujiono. (2013). Belajar dan Pembelajaran. Jakarta: Rineka Cipta.
Eko Putro Widoyoko. (2012). Teknik Penyusunan Instrumen Penelitian. Yogyakarta: Pustaka Pelajar.

Muhammad Munir (2014). Pengembangan Media Pembelajaran Interaktif Kompetensi Dasar Register Berbasis Inkutri Terbimbing Jurnal Penelitian Teknik dan Kejuruan. 22 (2), 184-190

Trianto. (2009). Mendesain Model Pembelajaran Inovatif Progresif. Jakarta: Kencana Prenada Media Group. . (2003). Undang Undang Nomor 20 tahun 2003 tentang Sistem Pendidikan Nasional. 